\title{
A role for prefrontal calcium-sensitive protein phosphatase and kinase activities in working memory
}

\author{
Jason D. Runyan, Anthony N. Moore, and Pramod K. Dash ${ }^{1}$ \\ The Vivian L. Smith Center for Neurological Research, Department of Neurobiology and Anatomy, The University of Texas \\ Medical School, Houston, Texas 77225, USA
}

\begin{abstract}
The prefrontal cortex is involved in the integration and interpretation of information for directing thoughts and planning action. Working memory is defined as the active maintenance of information in mind and is thought to lie at the core of many prefrontal functions. Although dopamine and other neurotransmitters have been implicated, the intracellular events activated by their receptors that influence working memory are poorly understood. We demonstrate that working memory involves transient changes in prefrontal $\mathrm{G}_{\mathrm{q} / 11}$-signaling and in calcium-dependent intracellular protein phosphatase and kinase activity. Interestingly, inhibition of the calcium activated phosphatase calcineurin impaired, while calcium/calmodulin dependent kinase II (CaMKII) and calcium-dependent protein kinase $\mathrm{C}(\mathrm{PKC})$ enhanced, working memory. Our findings suggest that the active maintenance of information required for working memory involves transient changes in the balance of these enzymes' activities.
\end{abstract}

The prefrontal cortex (PFC) is instrumental in the processing of information for guiding thought and intentional action, which are often referred to as executive function. Working memory, the process of actively maintaining and integrating information in mind for a relatively short period of time, underlies many prefrontal functions (Baddeley 1992). An example of this is holding a heard statement in mind to formulate an appropriate response during conversation. Electrophysiological recordings and functional imaging studies have indicated the involvement of the dorsolateral PFC in monkeys and humans in working memory (Fuster and Alexander 1971; Ungerleider et al. 1998). In rats, the medial part of the prefrontal cortex (mPFC) is considered to be the homolog of the primate dorsolateral PFC (Kolb 1984; Uylings and van Eden 1990). Within the PFC, depletion of dopamine or inhibition of dopamine D1/D5 receptor activity results in an impairment in working memory tasks (Brozoski et al. 1979; Kozlov et al. 2001). Interestingly, either insufficient (as in aging) or excessive (as in stress) prefrontal dopamine receptor stimulation can impair working memory (Goldman-Rakic et al. 2000). In addition to dopamine, norepinephrine, acetycholine, and serotonin have been implicated in working memory (Zahrt et al. 1997; Robbins et al. 2000).

"Delay cells" within the PFC of monkeys and rats have been shown to remain active throughout a time period in which animals are required to maintain information for a future response in delay match-to-sample working memory tasks (Fuster and Alexander 1971; Kojima and Goldman-Rakic 1982; Baeg et al. 2003). It is thought that modulatory neurotransmitters are involved in the maintenance of delay neuronal activity by influencing the reverberating activity within the PFC that subserves working memory (Hebb 1949; Fuster 1980). For example, local infusion of a dopamine D1/D5 receptor antagonist into the PFC interferes with delay period activity and working memory (Sawaguchi and Goldman-Rakic 1991; Sawaguchi 2001). Although the activity of D1 receptors is known to be involved working memory, it is not known how receptor stimulation is

\footnotetext{
'Corresponding author.

E-mail p.dash@uth.tmc.edu; fax (713) 500-0621.

Article and publication are at http://www.learnmem.org/cgi/doi/10.1101/ Im.89405.
}

linked to the active maintenance of information. In this report, we present pharmacological, behavioral, and biochemical evidence to demonstrate that calcium-activated protein phosphatase and kinase activities are critical for working memory.

\section{Results}

The delay match-to-place task is dependent on mPFC activity and is sensitive to prefrontal dopamine DI receptor modulation

Previous experimentation in humans, monkeys, and rats indicate that prefrontal D1/D5 receptor activity is required for working memory (Sawaguchi and Goldman-Rakic 1991; Seamans et al. 1998). Several investigators have employed the delay match-toplace to study working memory and its dysfunction in pathological conditions (Hamm et al. 1996; Waters et al. 1997; Steele and Morris 1999; Miyoshi et al. 2002; Dash et al. 2004). In this task, animals are required to locate a hidden escape platform (location trial), removed from the training context and then, following a 5-sec delay, placed back into the training context and allowed to relocate the platform (match trial). In order to demonstrate the necessity of prefrontal neuronal activity in this task, rats were infused with either $0.5 \mu \mathrm{g} /$ side muscimol $\left(\mathrm{a} \mathrm{GABA}_{\mathrm{A}}\right.$ receptor agonist) or vehicle, targeted to the $\mathrm{mPFC}$. Fifteen minutes later, animals were tested in the match-to-place task. Figure $1 \mathrm{~A}$ shows that vehicle-treated animals demonstrate intact working memory as indicated by a significant decrease in latency to platform during the match trials compared with the location trials. Muscimol-infused animals, by comparison, had match trial latencies that were not significantly different than those recorded for the location trials. This indicates that increasing the inhibitory component within the PFC disrupts working memory performance in the match-to-place task.

To corroborate the involvement of prefrontal dopamine D1/ D5 receptors in the match-to-place working memory task, animals received bilateral intra-mPFC infusions of the receptor antagonist SCH-23390 ( $1 \mu \mathrm{g} / \mathrm{side} ; n=7) 15 \mathrm{~min}$ prior to testing. This dose was based on previous studies demonstrating that intra-mPFC infusion impairs working memory and disrupts D1 receptor activity (Seamans et al. 1998). Animals receiving vehicle infusions exhibited a significant decrease in latency for the match 
A
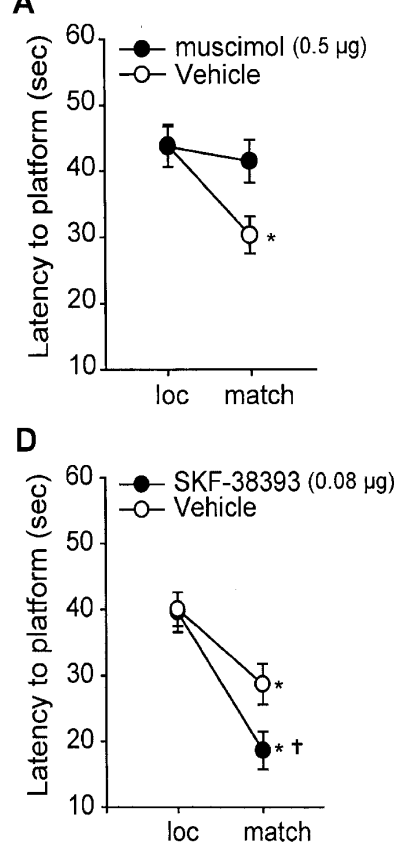

B

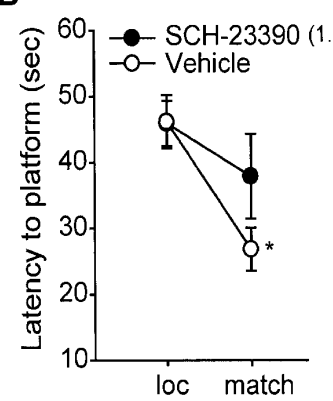

$\mathrm{E}$

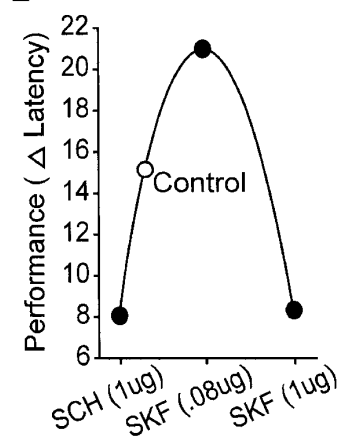

C

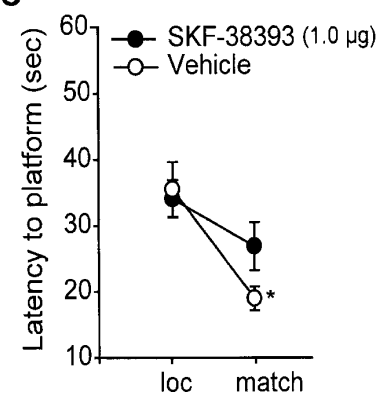

$\mathbf{F}$

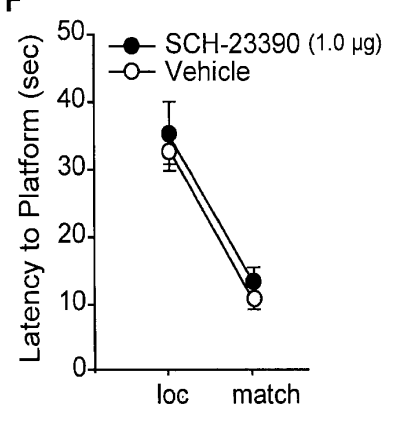

Figure 1. mPFC activity and D1 receptors are required for performance in a delay match-to-place working memory task. Average latency to hidden platform for location and match trials for animals infused into the mPFC with the following: $(A)$ muscimol $(0.5 \mu \mathrm{g})$, a GABA agonist; $(B) \mathrm{SCH}-23390(1$ $\mu \mathrm{g}), \mathrm{a}$ D1/D5 receptor antagonist; (C) SKF-38393 $(1 \mu \mathrm{g})$, a D1/D5 receptor agonist; and (D) SKF-38393 $(0.08 \mu \mathrm{g})$ compared with their respective vehicle infused controls. $(E)$ Working memory performance follows an inverted-U response curve to D1 receptor stimulation (expressed as the delta $[\Delta]$ latency between the location and match trials). ( $F$ ) Average latency to hidden platform for location and match trials for animals infused into the hippocampus with $\mathrm{SCH}-23390(1 \mu \mathrm{g}) .{ }^{*} P<0.05$ comparing location to match trials; $\uparrow P<0.05$ comparing match trials between groups.

trial, indicating normal working memory (loc $=46.2 \pm 4.0 \mathrm{sec}$ vs. match $=26.8 \pm 3.3 \mathrm{sec}, P<0.05$ ) (Fig. 1B). In contrast, SCH-23390infused animals $(n=7)$ did not show a significant decrease in latency during the match trial, indicating impaired working memory (loc $=45.9 \pm 3.4 \mathrm{sec}$ vs. match $=37.9 \pm 6.4 \mathrm{sec}, P=\mathrm{NS}$ ). Similar to this, infusion of $1 \mu \mathrm{g} /$ side of the D1/D5 receptor agonist SKF-39383 $(n=9)$ also impaired working memory (loc $=33.6 \pm 2.8$ vs. match $=25.3 \pm 3.6 \mathrm{sec}, P=\mathrm{NS})$ compared with that of vehicle controls $(n=7 ;$ loc $=35.0 \pm 4.2$ vs. match $=18.5 \pm 1.8 \mathrm{sec}, P<0.05)$ (Fig. 1C). While the vehicle group in this experiment showed lower location trial latencies than in other experiments, this reduction was also observed in the drug-infused animals, possibly as a result of the particular platform positions used in this study and interexperimental variability. When a lower concentration of SKF-39383 $(0.08 \mu \mathrm{g} / \mathrm{side})$ was infused into the mPFC (Fig. 1D), a group main effect was observed as a result of drug treatment $\left(F_{(1,12)}=5.938\right)$. Post-hoc analysis indicated that the D1 agonistinfused animals $(n=7)$ had significantly shorter latencies during the match trials than did the vehicle-infused controls $(n=7$; vehicle: match $=28.7 \pm 3.1 \mathrm{sec} ;$ SKF-38393: match $=18.6 \pm 2.9$ sec, $P<0.05$ ) (Fig. 1D). This effect suggests that modest D1 agonism improves spatial working memory. In all experiments with D1/D5 receptor agonists and antagonist, no difference was observed in the ability of the drug- and vehicle-infused groups to search and locate the hidden platform during the location trials, nor were any differences in swimming speed, motivation or visual acuity found (data not shown).

Previous studies have shown that either excessive or insufficient $\mathrm{mPFC}$ D1 receptor stimulation impairs working memory, giving rise to an inverted-U response curve (Sawaguchi and Gold-
man-Rakic 1991; Arnsten et al. 1994; Goldman-Rakic et al. 2000). Consistent with this, Figure 1E shows summary data from the D1 receptor experiments, demonstrating that both excessive and insufficient receptor stimulation within the PFC impairs working memory in this version of the match-to-place task. Further, consistent with previous studies showing partial or low levels of prefrontal D1 agonist can improve deficits in working memory (Arnsten et al. 1994; Castner et al. 2000; Goldman-Rakic et al. 2000), our data indicate that low levels of D1 agonist can optimize working memory. In order to confirm that the impairment of working memory following intra-mPFC D1 receptor antagonist infusion was not caused by diffusion of the drug into the hippocampus, $1 \mu \mathrm{g} /$ side SCH-23390 was directly infused into the dorsal hippocampus and working memory assessed. Figure $1 \mathrm{~F}$ shows that intrahippocampal D1 receptor antagonism did not influence working memory performance (vehicle: $l o c=32.9 \pm 2.0 \mathrm{sec}$ vs. match $=10.4 \pm 1.1 \mathrm{sec}, P<0.05$; $\mathrm{SCH}-$ 23390: 1 oc $=34.9 \pm 5.1$ sec vs. match $=13.1 \pm 2.3$ sec, $P<0.05$ ). This result is consistent with our previous findings that intra-mPFC infusion of drugs does not directly impact biochemical changes occurring within the hippocampus or other proximal structures (Runyan et al. 2004). Taken together, these results indicate that the delayed match-to-place task utilized in this study requires the active use of information over seconds and is sensitive to mPFC D1/D5 receptor manipulation, both of which are features of working memory.

\section{$\mathrm{G}_{\mathrm{q} / 11}$ translocation and phospholipase $\mathrm{C}$ activity in working memory}

Modulatory neurotransmitters involved in working memory engage $\mathrm{G}$ protein-coupled receptors to initiate intracellular signaling. For example, dopamine D1/D5 receptors are coupled to both $\mathrm{G}_{\mathrm{s}}$ and $\mathrm{G}_{\mathrm{q} / 11}$ proteins that can alter the levels of the intracellular second messengers cAMP and calcium. In response to receptor stimulation, $\mathrm{G}_{\mathrm{q} / 11} \alpha$ and $\mathrm{G}_{\mathrm{s}} \alpha$ are released from the plasma membrane (Levis and Bourne 1992; Arthur et al. 1999). To examine if the amount of membrane bound $\mathrm{G}_{\mathrm{q} / 11 \alpha}$ is altered during working memory, mPFC tissue samples $\left(\sim 1 \mathrm{~mm}^{3}\right)$ were harvested at various time-points from animals performing the working memory task. Following the location trial, animals were killed either immediately upon removal of the platform $(n=8)$, following a 20sec delay $(n=5)$, or following a 90-sec delay $(n=5)$. During the process of removal of the brain, ice-cold artificial cerebrospinal fluid (CSF) was poured onto the surface of the skull and exposed brain. Once the brain was removed, it was submerged in ice-cold artificial CSF, and mPFC tissue punches containing the prelimbic and infralimbic cortices (PL/IL) taken. On average, $\sim 2$ sec was required to decapitate the animal, with another $6-8 \mathrm{sec}$ required to remove the brain. Control tissue was prepared in a similar manner from animals yoked for swimming time (SWIM; $n=7$ ) and from naive animals $(n=5)$.

\section{Learning \& Memory}

www.learnmem.org 
The levels of membrane bound $\mathrm{G}_{\mathrm{q} / 11 \alpha}$ were investigated by Western blotting. Protein concentration was quantified for each sample and normalized for sample loading. Following protein transfer, the membrane was cut into high-molecular-weight $(<60$ $\mathrm{kDa})$ and low-molecular-weight ( $>60 \mathrm{kDa})$ sections and probed for $\mathrm{Na}^{+} / \mathrm{K}^{+}$ATPase, to further control for sample loading, and $\mathrm{G}_{\mathrm{q} / 11 \alpha}$, respectively. Figure $2 \mathrm{~A}$ shows that $\mathrm{G}_{\mathrm{q} / 11 \alpha}$ immunoreactivity was decreased in mPFC membrane extracts at the immediate time-point compared with timed swim controls (swim control: $100 \pm 4.9 \% ; W M$-immed: $79.4 \pm 5.0 \%, P<0.05)$. No significant difference in the immunoreactivity for $\mathrm{Na}^{+} / \mathrm{K}^{+}$ATPase was observed between the groups (swim control: $100 \pm 6.9 \%$; WMimmed: $100.7 \pm 8.2 \%, P=\mathrm{NS})$. $\mathrm{G}_{\mathrm{q} / 11 \alpha}$ immunoreactivity returned to control levels by the 90 -sec time-point. Likewise, when $\mathrm{G}_{\mathrm{s} \alpha}$ (which stimulates adenylyl cyclase to increase cAMP synthesis) immunoreactivity was investigated, no difference was found in between mPFC membrane extracts from animals at this timepoint (swim control: $100 \pm 14.3 \%$; WM-immed: $97.1 \pm 10.9 \%$, $P=$ NS). This is consistent with a previous study reporting that blockade of cAMP-dependent protein kinase A (PKA) activity by Rp-cAMPS did not influence working memory in a delay alternation task (Taylor et al. 1999).

Since activation of $\mathrm{G}_{\mathrm{q} / 11}$ increases phospholipase C (PLC) activity (Smrcka et al. 1991), we tested if PLC inhibition impaired working memory. Bilateral intra-mPFC infusions of a PLC inhibitor

A

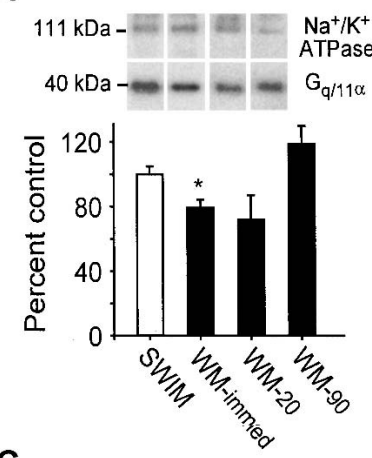

C

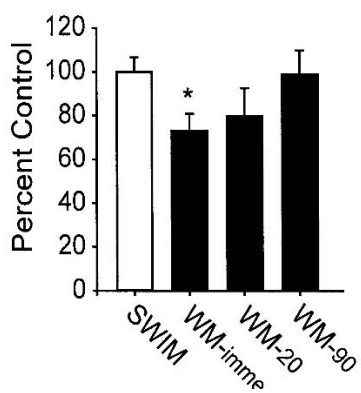

B

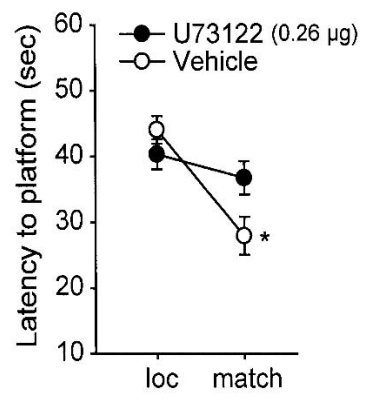

D

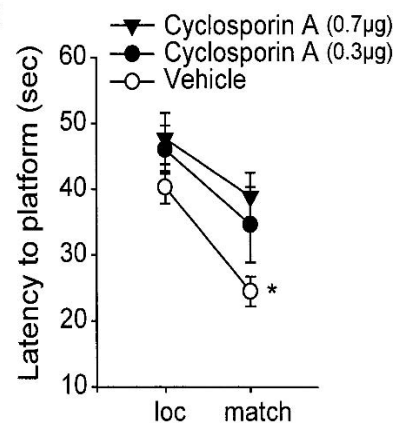

Figure 2. Spatial working memory involves PLC and calcineurin activities. $(A)$ Representative $\mathrm{G}_{\mathrm{q} / 11 \alpha}$ and $\mathrm{Na}^{+} / \mathrm{K}^{+}$ATPase Western blots performed on mPFC membrane extracts taken at time-points during the delay match-to-place task compared against swim controls. Summary results showing average $G_{q / 11 \alpha}$ immunoreactivity as a percentage of that obtained for swim controls. ${ }^{*} P<0.05$. (B) Average latency to hidden platform for location trials and match trials during the delay match-toplace task for intra-mPFC infused vehicle and U73122 $(0.26 \mu \mathrm{g})$. ${ }^{*} P<0.05$ comparing location to match trials; $\uparrow P<0.05$ comparing match trials between groups. (C) mPFC calcineurin activity expressed as percentage swim control at time-points during the delay match-to-place working memory task. ${ }^{*} P<0.05$. (D) Average latency to hidden platform for location and match trials during the delay match-to-place task for intra-mPFC vehicle, and cyclosporin A $(0.3 \mu \mathrm{g}$ or $0.7 \mu \mathrm{g})$ animals. ${ }^{*} P<0.05$ comparing location to match trials.

U73122 $(0.26 \mu \mathrm{g} / \mathrm{side} ; n=15)$ or vehicle $(n=12)$ were performed prior to testing. Figure $2 \mathrm{~B}$ shows that animals that received U73122 had impaired working memory, as indicated by a lack of significant improvement in the match compared with the location trials (vehicle: $l o c=44.7 \pm 2.9 \mathrm{sec}$ vs. match $=29.3 \pm 3.6 \mathrm{sec}$, $P<0.05$; U71223: loc $=39.9 \pm 2.8 \mathrm{sec}$ vs. match $=36.6 \pm 4.0 \mathrm{sec}$, $P=$ NS). No between-group difference in latency to a visible platform $($ vehicle $=15.9 \pm 2.9 \mathrm{sec}$; U73122=16.2 $\pm 3.0 \mathrm{sec}$, $P=\mathrm{NS}$ ) or in swimming speed (vehicle $=24.9 \pm 0.4 \mathrm{~cm} / \mathrm{sec}$; $\mathrm{U} 73122=26.0 \pm 1.5 \mathrm{~cm} / \mathrm{sec}, P=\mathrm{NS}$ ) was detected, suggesting that the observed working memory deficits were not due to differences in motor function or motivational state.

\section{Calcineurin activity is required for working memory}

Once activated, PLC hydrolyzes inositol phospholipids to generate diacylglycerols (DAG) and $\mathrm{IP}_{3}$. These lipid products, as well as PLC itself, increase intracellular calcium (Taylor 2002), leading to the activation of calcium-dependent enzymes such as calcium/ calmodulin-dependent protein phosphatase (calcineurin) and kinases (e.g., CaMKII and PKC), which are highly abundant in the PFC. To examine if mPFC calcineurin activity changes during working memory, an in vitro dephosphorylation assay was performed by using a calcineurin-specific phosphopeptide. No difference in calcineurin activity was observed between naive $(n=5)$ and swim control mPFC samples (naive: $0.37 \pm 0.06$ vs. SWIM: $0.35 \pm 0.04$ nmole phosphate released $/ \mathrm{min} / \mathrm{mg}$ protein). However, a significant decrease in calcineurin activity was observed in the mPFC samples at the immediate time-point $(n=7)$ compared with the swim control group $(n=8 ; P<0.05)$ (Fig. $2 \mathrm{C})$. This decrease had returned to control levels by the 20 -sec timepoint.

To test the role of calcineurin activity in working memory, animals received bilateral intra-mPFC infusions of either $0.3 \mu \mathrm{g} /$ side $(n=8)$ or $0.7 \mu \mathrm{g} / \mathrm{side}(n=7)$ of the calcineurin inhibitor cyclosporin A, a selective calcineurin inhibitor (Li and Handschumacher 1993) prior to testing. Animals that received either dose of the inhibitor had latencies similar to vehicle-infused animals $(n=8)$ during the location trials but were unable to find the hidden platform during the match trials significantly faster, indicating a working memory deficit (vehicle: $l o c=40.3 \pm 2.5 \mathrm{sec}$ vs. match $=24.5 \pm 2.3 \mathrm{sec}, P<0.05$; cyclosporin A, $0.3 \mu \mathrm{g}$ : loc $=46.0 \pm 3.7 \mathrm{sec}$ vs. match $=34.6 \pm 5.7 \mathrm{sec}, P=\mathrm{NS}$; cyclosporin A, $0.7 \mu \mathrm{g}$ : $\operatorname{loc}=47.7 \pm 3.9 \mathrm{sec}$ vs. match $=38.9 \pm 3.6 \mathrm{sec}$, $P=$ NS) (Fig. 2D). No difference in latency to a visible platform was observed between the groups (vehicle $=15.1 \pm 2.7 \mathrm{sec}$; cyclosporin, A $0.7 \mu \mathrm{g}=14.0 \pm 3.5 \mathrm{sec}, P=\mathrm{NS}$ ).

\section{CaMKII and PKC activity negatively influence working memory}

Following binding to calcium/calmodulin, CaMKII is autophosphorylated at the $\mathrm{Thr}^{286}$ residue, which can be used as a marker for its activation (Meyer et al. 1992; Mukherji et al. 1994). By using an antibody specific for phoshorylated $\mathrm{Thr}^{286}$, immunohistochemical staining of mPFC sections revealed a qualitative increase in CaMKII phosphorylation (pCaMKII) at the immediate second time-point during the working memory task compared with swim controls (Fig. 3A). pCaMKII immunoreactivity was found to be predominantly localized within layer II of the mPFC with expression also in layers III through V. Counts of doublelabeled cells revealed that 96\% (145 of 151) of all pCaMKIIpositive cells (green) were also positive for the neuronal marker NeuN (Fig. 3A, red). No detectable pCaMKII expression was observed in GFAP-expressing astrocytes (Fig. 3B) or in inhibitory neurons as indicated by GAD67 immunoreactivity (Fig. 3C). 
A
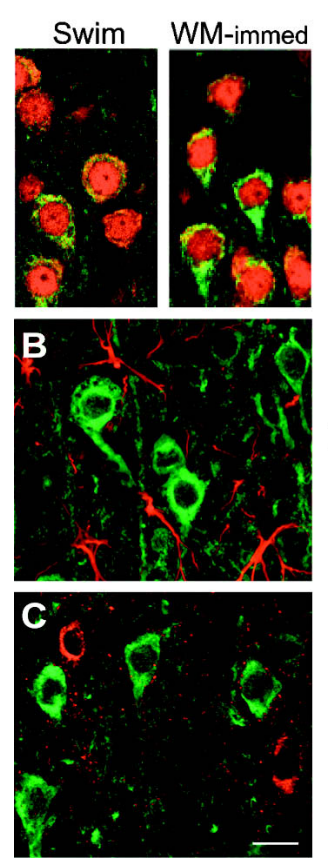

D

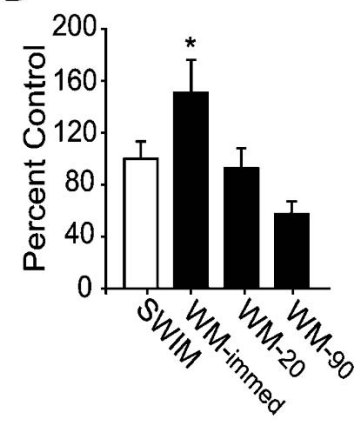

E

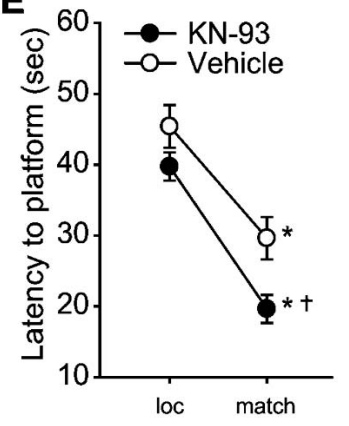

Figure 3. CaMKII activity negatively influences spatial working memory. (A) Representative confocal images of phospho-CaMKII (green) and NeuN (red) immunoreactivity of mPFC tissue sections taken from animals performing the working memory task (immediate) or from swim control. Phospho-CaMKII immunoreactivity was not detected in GFAPexpressing astrocytes (red) (B) or GAD67-expressing inhibitory neurons (C). Scale bar for all images $=10 \mu \mathrm{m}$. (D) mPFC CaMKII activity expressed as percent swim control at time-points during the delay match-to-place working memory task. (E) Average latency to hidden platform for location and match trials for intra-mPFC KN-93-infused $(1 \mu \mathrm{g})$, a CaMKII inhibitor, or vehicle-infused animals. ${ }^{*} P<0.05$ comparing location to match trials; $\dagger P<0.05$ comparing match trials between groups.

To quantify CaMK activity during the working memory task, an in vitro phosphorylation assay using mPFC protein extracts was utilized. This assay has been extensively used to examine CaMK activity, and the peptide used has been shown to be a specific substrate for CaMK (Klann et al. 1993; Moore et al. 1996). In extracts from control animals, the unstimulated activity of CaMK was found to be $0.90 \pm 0.04 \mathrm{nmol}$ of ATP transferred/ $\mathrm{min} / \mathrm{mg}$ protein. Figure $3 \mathrm{D}$ shows that CaMK activity in the mPFC significantly increased at the immediate time-point $(n=7)$ compared with swim controls $(n=8, P<0.05)$. This increase had subsided by $20 \mathrm{sec}$. To test if CaMKII activity is involved in working memory, animals received intra-mPFC infusions of $\mathrm{KN}$ $93(1 \mu \mathrm{g} / \mathrm{side})$ or vehicle prior to testing. Although both the vehicle-treated $(n=9)$ and KN-93-treated $(n=8)$ animals demonstrated intact working memory as evidenced by significantly lower latencies during the match trials compared to the location trials (Fig. 3E), comparisons between the groups revealed a significant group main effect $\left(F_{(1,15)}=7.896\right)$. Post-hoc analysis revealed that the CaMKII inhibitor-treated animals found the hidden escape platform significantly faster during the match trials than did their vehicle-treated counterparts (vehicle: match $=29.6 \pm 3.0 \mathrm{sec} ; \mathrm{KN}-93:$ match $=19.6 \pm 2.0 \mathrm{sec}$, $P<0.05)$, with no difference in the location trials. This indicates that inhibition of MPFC CaMKII activity resulted in an enhancement in working memory performance. There were no betweengroup differences in the latency to the hidden platform during the location trials, and both groups had comparable swim velocities (vehicle $=24.1 \pm 3.4 \mathrm{~cm} / \mathrm{sec} ; \mathrm{KN}-93=23.7 \pm 1.2 \mathrm{~cm} / \mathrm{sec}, P=\mathrm{NS}$ ).

Protein kinase $\mathrm{C}$ (PKC) can also be activated by calcium and has been implicated in regulating persistent activity in PFC slice preparations (Young and Yang 2004). We therefore tested whether changes in PKC activity occur during working memory. The activity assay and substrate peptide used has been previously characterized (Klann et al. 1993). In extracts from control animals, the unstimulated activity of PKC was found to be $0.07 \pm 0.02 \mathrm{nmol}$ of ATP transferred $/ \mathrm{min} / \mathrm{mg}$ protein. Figure $4 \mathrm{~A}$ shows an increase in PKC activity in $\mathrm{MPFC}$ protein samples at the 20 -sec time-point compared with the swim control samples $(P<0.05)$. This increase returned to control levels by $90 \mathrm{sec}$ (Fig. $4 \mathrm{~A})$. To test the role of PKC activity in working memory performance, bilateral intra-mPFC infusion of a broad spectrum PKC inhibitor, GF109203X ( $1 \mu \mathrm{g} / \mathrm{side})$, was performed before testing. Both the GF109203X-treated $(n=11)$ and vehicle-treated $(n=11)$ animals had significantly shorter latencies to the platform during the match trial compared with the location trial (Fig. 4B). However, a main effect of drug administration was detected $\left(F_{(1,20)}=4.724\right)$ with the GF109203X-infused animals finding the platform significantly faster during the match trials than the vehicle group (vehicle: match $=30.9 \pm 3.5$ sec; GF109203X: match $=22.2 \pm 2.1 \mathrm{sec}, P<0.05)$. No significant difference in the location was detected. To specifically test if calcium-sensitive isoforms of PKC are involved, bilateral intra-mPFC infusions of the calcium-sensitive PKC isoform inhibitor Gö6976 (1 $\mu \mathrm{g} / \mathrm{side})$ were performed. Similar to the broad spectrum PKC inhibitor, infusion of Gö6976 ( $n=9)$ significantly improved working memory performance compared with vehicle-infused controls $\left(n=9 ; F_{(1,16)}=5.445\right.$; vehicle: match $=28.0 \pm 3.8$ sec; Gö 6976: match $=17.6 \pm 2.2 \mathrm{sec}, P<0.05$ ) (Fig. 4C). In both PKC inhibitor
A
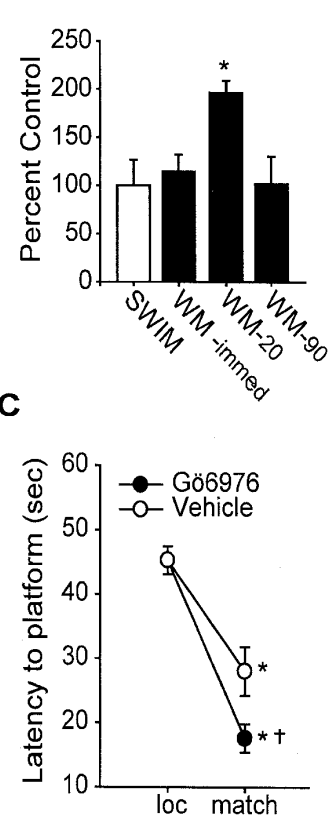

B
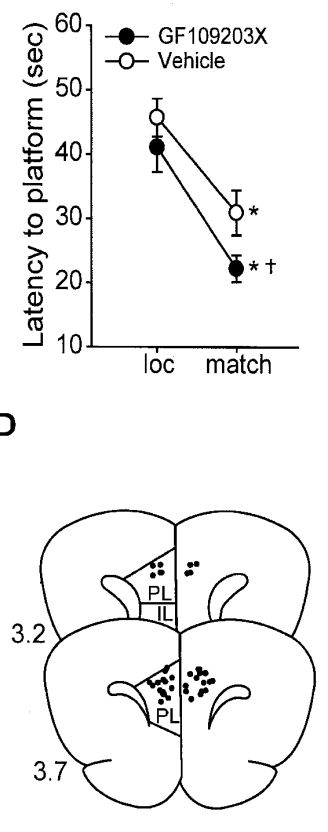

Figure 4. PKC activity negatively influences performance in the delay match-to-place task. (A) PKC activity expressed as percent swim control at time-points during the working memory task. Average latency to hidden platform for location and match trials for intra-mPFC. (B) GF109203X $(1 \mu \mathrm{g})$, a PKC inhibitor, and (C) Gö6976-infused $(1 \mu \mathrm{g}), \mathrm{a} \mathrm{Ca} \mathrm{Ca}^{2+}$ dependent PKC inhibitor, animals compared with vehicle controls. (D) Illustration of coronal sections ( $3.2 \mathrm{~mm}$ and $3.7 \mathrm{~mm}$ to bregma) of the $\mathrm{mPFC}$ indicating the non-redundant infusion sites for the animals in this study. ${ }^{*} P<0.05$ comparing location to match trials; $\uparrow P<0.05$ comparing match trials between groups. 
studies, there was no between-group difference in latency to the platform during location trials or in swim velocity (vehicle $=23.9 \pm 1.0 \mathrm{~cm} / \mathrm{sec} ;$ GF109203X $=26.8 \pm 1.8 \mathrm{~cm} / \mathrm{sec}$, $P=\mathrm{NS}$; vehicle $=19.3 \pm 3.2 \mathrm{~cm} / \mathrm{sec} ;$ Gö $6976=19.7 \pm 1.6 \mathrm{~cm} /$ sec, $P=$ NS). Following the completion of all behavioral studies, cannulae placement was assessed. Figure $4 \mathrm{D}$ shows coronal illustrations of the mPFC with the non-redundant infusion sites indicated. All infusions were found to be within the PL/IL cortices.

\section{Discussion}

It is known that prefrontal activity (Fuster and Alexander 1971) and dopamine (Sawaguchi and Goldman-Rakic 1991) are critical for working memory. Although reverberating neuronal activity within the PFC is thought to be required for working memory, the contribution of intracellular changes to this process is poorly understood. In the present study, we show that working memory results in transient changes in the activity of the calciumactivated enzymes calcineurin, CaMKII, and PKC within the PFC. Changes in enzymatic activity were observed as a result of the working memory task and not following swimming alone. Working memory impairments as a result of inhibition of calcineurin, as well as enhancements as a result of inhibition of CaMKII and PKC, suggests that these calcium-activated signaling molecules may play opposing roles in working memory. In addition to delay cell activity, the present findings support a role for the protein phosphatase calcineurin in working memory, suggesting that protein dephosphorylation may be required for this process. Consistent with a role for protein dephosphorylation in working memory, we found that calcium-sensitive protein kinase activities have a negative influence. These findings stand in contrast to the roles of these molecules in long-term memory storage in which attenuation of calcineurin activity enhances (Malleret et al. 2001) and inhibition of kinase activities impair long-term memory (Silva et al. 1992; Mayford et al. 1995; Kandel 2001).

We observed a decrease in calcineurin activity, as well as increases in CaMK and PKC activities, in prefrontal samples prepared following the location trial in the delay match-to-place working memory task. Calcineurin has a higher affinity for the calcium/calmodulin complex than does CaMKII (Mulkey et al. 1994; D'Alcantara et al. 2003) and is preferentially activated at moderate intracellular calcium concentrations. It is therefore possible that a transient increase in prefrontal calcineurin activity occurred, which we were unable to detect due to the temporal limitations inherent in the sample preparation protocol. This poses the possibility that as delay period activity persists, calcium accumulation could result in the activation of CaMKII, as well as calcium-dependent PKC isoforms. Though the CaMK assay employed does not distinguish between CaMKII and CaMKIV isoforms, and the PKC substrate can be phosphorylated by both calcium-dependent and -independent isoforms of PKC, our pharmacological and immunohistochemical studies implicate CaMKII and calcium-dependent PKC isoforms in working memory. As CaMKII becomes autophosphorylated, calcium/ calmodulin availability decreases due to the trapping of calmodulin (Meyer et al. 1992). A sequestration of calmodulin by phosphorylated CaMKII could decrease the availability of calmodulin, thereby decreasing calcineurin activity. However, this possibility remains to be demonstrated experimentally.

Our enzyme activity measurements in mPFC tissue following working memory training revealed an $\sim 25 \%$ decrease in calcineurin activity, while CaMK and PKC activities were found to be enhanced by $50 \%$ and $90 \%$, respectively. Ideally, to assess the role of these training-related changes, genetic and pharmacologi- cal interventions should target only these changes, leaving basal enzymatic activity unperturbed. Unfortunately, this is technically difficult, and a common problem associated with the use of pharmacological inhibitors is that the degree of pharmacological inhibition is likely to exceed the temporal limitations of the observed biochemical event. Therefore, one could not definitively conclude that the behavioral effect observed following administration of a pharmacological inhibitor is due to the blockade of a training-related change rather than inhibition of basal activity. However, it has been previously demonstrated that the inhibitors used in this study do not alter basal synaptic transmission in brain slices (which results from the direct binding of calcium brought in by the action potential to synaptotagmin causing fusion of synaptic vessels and transmitter release) (Mulkey et al. 1994; Margrie et al. 1998; Camodeca et al. 1999; Edagawa et al. 2000). This suggests that the influences of the inhibitors we observed are likely to be due not to blockade of basal neuronal activity but rather to an influence on the mechanism underlying working memory.

The behavioral data showed that inhibition of calcineurin activity by cyclosporin A impairs working memory, suggesting that increased substrate phosphorylation has a negative influence on this process. Alternatively, while a moderate decrease in calcineurin activity and increased substrate phosphorylation may be necessary for working memory, further inhibition may be detrimental. However, if an increase in substrate phosphorylation were necessary for working memory, then it would be expected that inhibition of kinase activity would also impair working memory, the opposite of which was seen in this study. One caveat with the use of cyclosporin A in these experiments is that it acts to inhibit calcinuerin through its interaction with cyclophilins. As cyclophilins have peptidyl prolyl cis-trans isomerase activity and are involved in protein folding, the contribution of this function of cyclophilins on targets other than calcineurin cannot be excluded.

Although the working memory-related substrate(s) whose phosphorylation changes as a result of working memory training are not known at present, calcineurin has been reported to increase neuronal activity through decreasing the phosphorylation of potassium and calcium channels (Roeper et al. 1997; Day et al. 2002). A shift in the balance of phosphatase/kinase activity toward substrate dephosphorylation (e.g., ion channels) may be required for delay period activity. Furthermore, it has been recently observed that the activity of individual entorhinal cortex neurons can be maintained as a result of calcium influx and modulation of calcium-sensitive cation channels (Egorov et al. 2002). However, it is not known if this modulation is due to a direct effect of calcium, or via calcium-sensitive kinases and phosphatases. Although our findings indicate that CaMKII and PKC activities negatively influence working memory, whether these kinases are involved in the termination of delay cell activity and working memory remains to be investigated.

Taken together, these data suggest that alterations in the balance of phosphatase and kinase activities as a result of pathological conditions would disrupt working memory performance, and that modulation of their activities in favor of substrate dephosphorylation would be beneficial. In support of this, we have recently observed that traumatic brain injury-associated working memory deficits can be relieved by the targeted infusion of a CaMKII inhibitor into the PFC (P.K. Dash, unpubl.). Further experimentation will be needed to explore the substrates of these enzymes that mediate the changes in prefrontal neuronal activity states underlying working memory, and to determine if alterations in these processes contribute to deficits in working memory duration associated with disease and age-related memory decline. 


\section{Materials and Methods}

\section{Surgery}

Male Sprague-Dawley rats were implanted under isofurane anesthesia with sterile stainless-steel guide cannulae aimed at the dorsal border of the prelimbic area using a stereotaxic device (Bregma $3.2 \mathrm{~mm}$, lateral \pm 0.75 , and depth $-2.5 \mathrm{~mm}$ ) as previously described (Runyan and Dash 2004). Animals were allowed to recover from the surgery for $10 \mathrm{~d}$ prior to behavioral testing. Animal protocols were approved by the Institutional Animal Welfare Committee and were in compliance with National Institutes of Health Guide for Care and Use of Laboratory Animals.

\section{Behavioral protocol}

All behavior tests were performed by an investigator blind to the treatment groups. Twenty-four hours before testing, animals were given five training trials in a working memory version of the Morris water maze task (delay match-to-place task) (Hamm et al. 1996; Steele and Morris 1999; Kline et al. 2002) in order to familiarize them with the task. Each testing session consisted of a location trial, a 5-sec delay, and a match trial. Each location trial was started from a random location with the hidden platform in a novel position. Once the platform was found, the animal was allowed to rest on it for $10 \mathrm{sec}$. The animal was then removed from the hidden platform for a 5-sec delay period (and placed in the holding area). Following the delay, the animal was placed back into the water maze and allowed to search for the platform (the match trial). If the animal failed to locate the platform within $60 \mathrm{sec}$ on any given trial, it was led there by the investigator. After each testing session, the animal is given a 4-min intertrial interval (iti) before the next testing session with a new platform location. The influence of each drug on working memory performance was assessed in four testing sessions. Swimming speed was calculated by dividing the distance traveled by the latency to reach the platform. Motivation and visual acuity was assessed by using latency in a visible platform test.

\section{Infusions}

All drugs were dissolved in DMSO except for SCH-23390, which was dissolved in saline. Stock solutions were diluted in saline before use. Vehicle controls consisted of the same dilution of DMSO in saline as their drug solution counterparts. Infusions $(0.25 \mu \mathrm{L} / \mathrm{min}$ for $2 \mathrm{~min})$ were carried out $15 \mathrm{~min}$ prior to working memory testing. Following infusion, the cannulae were left in place for 2 min to allow for diffusion of the drug. Dosages of inhibitors used here were based on previous in vivo studies, and their specificities have been extensively characterized (Sibley et al. 1982; Hyttel 1983; Liu et al. 1991; Sumi et al. 1991; Toullec et al. 1991; Yule and Williams 1992).

\section{Tissue preparations}

Animals were trained and tested as described above. Either immediately, or 20 sec or 90 sec following removal from the hidden platform after the fourth location trial during the working memory task, animals were decapitated and mPFC punches $(\sim 1$ $\mathrm{mm}^{3}$ ) were harvested. During brain removal ice-cold artificial CSF was continuously poured onto the skull and brains. The procedure of decapitation and removal of the brain required an average of $10 \mathrm{sec}$. For the longer time-points, animals remained in the holding area that was used in between the location and match trials. Control tissue was obtained from animals yoked for swimming time or from naive animals. mPFC tissue was homogenized with a motorized glass-Teflon homogenizer in a buffer containing $10 \mathrm{mM}$ Tris/HCl (pH 7.4), 1 mM EGTA, 1 mM EDTA, $0.5 \mathrm{mM}$ DTT, $0.5 \mathrm{mM}$ PMSF, $10 \mu \mathrm{g} / \mathrm{mL}$ leupeptin. These samples were stored at $-80^{\circ} \mathrm{C}$ until needed. For Western blot analysis, homogenates were centrifuged for $45 \mathrm{~min}$ at $20,000 \mathrm{~g}$, and the pelletized material was resuspended in homogenization buffer by sonication. The protein concentration in each sample was determined by a Bradford assay using BSA as the standard, and equal amounts of protein were loaded on SDS-PAGE gels. Following transfer, the membrane (Immobilon P, Millipore) was cut below the migration of $\mathrm{Na}^{+} / \mathrm{K}^{+}$ATPase. The immunoreactive bands for $\mathrm{G}_{\mathrm{q} / 11} \alpha$ and $\mathrm{G}_{\mathrm{s}} \alpha$ were normalized against those obtained for $\mathrm{Na}^{+}$/ $\mathrm{K}^{+}$ATPase from the same gel. Immunoreactivity was detected by an alkaline phosphatase-based chemilumenescence system (CDP-Star; New England Biolabs), with multiple exposures being made to ensure the linearity of the product.

\section{Calcineurin assay}

Calcineurin activity was measured by using the Quantizyme Assay System AK-804, as described by the vendor (Biomol, Inc.). Standard curves were performed as outlined in the assay kit in order to establish a linear range for the reactions. A 2-min reaction using $4 \mu \mathrm{L}(\sim 0.2 \mu \mathrm{g} / \mu \mathrm{L})$ of homogenate was performed.

\section{Protein kinase assays}

CaMK activity was measured by using the synthetic peptide substrate autocamtide-3 (KKALHRQETVDAL) (Moore et al. 1996). Phosphorylation reactions were initiated by adding $4 \mu \mathrm{L}(\sim 0.2$ $\mu \mathrm{g} / \mu \mathrm{L})$ of protein to a $20 \mu \mathrm{L}$ mixture, resulting in the following final concentrations: $10 \mathrm{mM}$ HEPES ( $\mathrm{pH} 7.4$ ), $0.5 \mathrm{mM}$ DTT, 20 $\mu \mathrm{M}$ substrate peptide, $50 \mu \mathrm{M}$ ATP, $2.5 \mathrm{mM}$ EGTA, $5 \mathrm{mM} \mathrm{MgCl}_{2}$ $0.1 \mathrm{mM}$ PMSF, $10 \mu \mathrm{g} / \mathrm{ml}$ leupeptin, and $2 \mu \mathrm{Ci}$ of $\left[\gamma^{32} \mathrm{P}\right] \mathrm{ATP}(3000$ $\mathrm{Ci} / \mathrm{mmole})$. After a $1-\mathrm{min}$ incubation at $30^{\circ} \mathrm{C}$, the reactions were spotted $(15 \mu \mathrm{L})$ on $\mathrm{P}-81$ phosphocellulose filters. The filters were washed three times, $10 \mathrm{~min}$ each, in $75 \mathrm{mM}$ phosphoric acid, rinsed with ethanol, and dried under air flow. Radioactivity on the phosphorylated peptide substrate was quantified in a scintillation counter by the Cerenkov method. Control reactions for determination of background counts were prepared simultaneously by omitting the substrate peptide. Counts were normalized by using protein concentrations determined by a Bradford assay.

PKC activity was measured by using a specific substrate peptide (AAAKIQASFRGHMAR) as described previously (Klann et al. 1993). The assay mixture consisted of $20 \mathrm{mM}$ HEPES ( $\mathrm{pH} 7.4)$, $10 \mathrm{mM} \mathrm{MgCl}, 2 \mathrm{mM} \mathrm{NaPPi}, 0.1 \mathrm{mM}$ PMSF, $100 \mu \mathrm{M}$ ATP, $2 \mu \mathrm{Ci}$ of $\left[\gamma^{32} \mathrm{P}\right] \mathrm{ATP}$, and $20 \mu \mathrm{M}$ substrate peptide. The reaction mixture was incubated with $4 \mu \mathrm{L}$ of protein extract for $2 \mathrm{~min}$ at $30^{\circ} \mathrm{C}$. The reactions were spotted on P81 paper and processed as described above.

\section{Immunohistochemistry}

Tissue was isolated and post-fixed in ice-cold $4 \%$ paraformaldehyde/15\% picric acid as described previously (Moore et al. 1996). Immunohistochemistry was performed on free-floating $40 \mathrm{mi}-$ cron-thick slices by using $2 \mu \mathrm{g} / \mathrm{mL}$ of phosho-CaMKII $\left(\mathrm{Thr}^{286}\right.$ ) antibodies (Cell Signaling, Inc.). Immunoreactivity was visualized using a species-specific secondary antibody conjugated to Alexa-568 fluorochrome (Molecular Probes). Double-label immunohistochemistry was performed by using the phospho-CaMKII $\left(\mathrm{Thr}^{286}\right)$ antibody and an antibody against the neuronal marker NeuN, or an antibody against the inhibitory neuronal marker GAD67. NeuN or GAD67 $(1 \mu \mathrm{g} / \mathrm{mL})$ was visualized by using a species-specific secondary antibody conjugated to Alexa-488 fluorochrome. Confocal microscopy (three sections/animal) was utilized to quantify the cell types expressing phospho-CaMKII.

\section{Data analysis}

A two-way repeated-measures ANOVA was used for statistical evaluation of differences in latency to the platform between experimental and control groups in location and match trials. In addition, a one-way repeated-measures ANOVA was also used to examine differences in immunoreactivity and enzymatic activity between experimental conditions. A $P<0.05$ was used as the criterion for significance. Post-hoc examination was performed by using the Tukey or Fisher tests, where appropriate.

\section{Acknowledgments}

We thank Drs. John H. Byrne, Anne Sereno, and James Knierim for insightful comments. We thank Melanie Moody, Sara Orsi, 
and April Hebert for assistance. This work was supported by National Institutes of Health grant NS 35457.

\section{Note added in proof}

During the review of this manuscript, a study by Birnbaum et al. (2004) showed that overactivation of PKC as a result of stress causes working memory dysfunction.

\section{References}

Arnsten, A.F., Cai, J.X., Murphy, B.L., and Goldman-Rakic, P.S. 1994. Dopamine D1 receptor mechanisms in the cognitive performance of young adult and aged monkeys. Psychopharmacology 116: 143-151.

Arthur, J.M., Collinsworth, G.P., Gettys, T.W., and Raymond, J.R. 1999 Agonist-induced translocation of Gq/11 $\alpha$ immunoreactivity directly from plasma membrane in MDCK cells. Am. J. Physiol. 276: F528-F534.

Baddeley, A. 1992. Working memory. Science 255: 556-559.

Baeg, E.H., Kim, Y.B., Huh, K., Mook-Jung, I., Kim, H.T., and Jung, M.W. 2003. Dynamics of population code for working memory in the prefrontal cortex. Neuron 40: 177-188.

Birnbaum, S.G., Yuan, P.X., Wang, M., Vijayraghavan, S., Bloom, A.K., Davis, D.J., Gobeske, K.T., Sweatt, J.D., Manji, H.K., and Arnsten, A.F. 2004. Protein kinase C overactivity impairs prefrontal cortica regulation of working memory. Science 306: 882-884.

Brozoski, T.J., Brown, R.M., Rosvold, H.E., and Goldman, P.S. 1979. Cognitive deficit caused by regional depletion of dopamine in prefrontal cortex of rhesus monkey. Science 205: 929-932.

Camodeca, N., Breakwell, N.A., Rowan, M.J., and Anwyl, R. 1999. Induction of LTD by activation of group I mGluR in the dentate gyrus in vitro. Neuropharmacology 38: 1597-1606.

Castner, S.A., Williams, G.V., and Goldman-Rakic, P.S. 2000. Reversal of antipsychotic-induced working memory deficits by short-term dopamine D1 receptor stimulation. Science 287: 2020-2022.

D'Alcantara, P., Schiffmann, S.N., and Swillens, S. 2003. Bidirectional synaptic plasticity as a consequence of interdependent $\mathrm{Ca}^{2+}$-controlled phosphorylation and dephosphorylation pathways. Eur. J. Neurosci. 17: 2521-2528.

Dash, P.K., Moore, A.N., Moody, M.R., Treadwell, R., Felix, J.L., and Clifton, G.L. 2004. Post-trauma administration of caffeine plus ethanol reduces contusion volume and improves working memory in rats. J. Neurotrauma 21: 1573-1583.

Day, M., Olson, P.A., Platzer, J., Striessnig, J., and Surmeier, D.J. 2002 Stimulation of 5-HT(2) receptors in prefrontal pyramidal neurons inhibits $\mathrm{Ca}(\mathrm{v}) 1.2 \mathrm{~L}$ type $\mathrm{Ca}^{2+}$ currents via a PLC $\beta / \mathrm{IP} 3 /$ calcineurin signaling cascade. J. Neurophysiol. 87: 2490-2504.

Edagawa, Y., Saito, H., and Abe, K. 2000. The serotonin 5-HT2 receptor-phospholipase $\mathrm{C}$ system inhibits the induction of long-term potentiation in the rat visual cortex. Eur. J. Neurosci. 12: 1391-1396.

Egorov, A.V., Hamam, B.N., Fransen, E., Hasselmo, M.E., and Alonso, A.A. 2002. Graded persistent activity in entorhinal cortex neurons. Nature 420: $173-178$.

Fuster, J.M. 1980. The prefrontal cortex. Raven Press, New York.

Fuster, J.M. and Alexander, G.E. 1971. Neuron activity related to short-term memory. Science 173: 652-654.

Goldman-Rakic, P.S., Muly III, E.C., and Williams, G.V. 2000. D(1) receptors in prefrontal cells and circuits. Brain Res. Brain Res. Rev. 31: $295-301$.

Hamm, R.J., Temple, M.D., Pike, B.R., O'Dell, D.M., Buck, D.L., and Lyeth, B.G. 1996. Working memory deficits following traumatic brain injury in the rat. J. Neurotrauma 13: 317-323.

Hebb, D.O. 1949. The organization of behavior: A neuropsychological theory. Wiley, New York.

Hyttel, J. 1983. SCH 23390: The first selective dopamine D-1 antagonist. Eur. J. Pharmacol. 91: 153-154.

Kandel, E.R. 2001. The molecular biology of memory storage: A dialogue between genes and synapses. Science 294: 1030-1038.

Klann, E., Chen, S.J., and Sweatt, J.D. 1993. Mechanism of protein kinase $\mathrm{C}$ activation during the induction and maintenance of long-term potentiation probed using a selective peptide substrate. Proc. Natl. Acad. Sci. 90: 8337-8341.

Kline, A.E., Massucci, J.L., Marion, D.W., and Dixon, C.E. 2002. Attenuation of working memory and spatial acquisition deficits after a delayed and chronic bromocriptine treatment regimen in rats subjected to traumatic brain injury by controlled cortical impact. J. Neurotrauma 19: 415-425.

Kojima, S. and Goldman-Rakic, P.S. 1982. Delay-related activity of prefrontal neurons in rhesus monkeys performing delayed response. Brain Res. 248: 43-49.

Kolb, B. 1984. Functions of the frontal cortex of the rat: A comparative review. Brain Res. 320: $65-98$.
Kozlov, A.P., Druzin, M.Y., Kurzina, N.P., and Malinina, E.P. 2001. The role of D1-dependent dopaminergic mechanisms of the frontal cortex in delayed responding in rats. Neurosci. Behav. Physiol. 31: $405-411$.

Levis, M.J. and Bourne, H.R. 1992. Activation of the $\alpha$ subunit of Gs in intact cells alters its abundance, rate of degradation, and membrane avidity. J. Cell. Biol. 119: 1297-1307.

Li, W. and Handschumacher, R.E. 1993. Specific interaction of the cyclophilin-cyclosporin complex with the B subunit of calcineurin. I. Biol. Chem. 268: 14040-14044.

Liu, J., Farmer Jr., J.D., Lane, W.S., Friedman, J., Weissman, I., and Schreiber, S.L. 1991. Calcineurin is a common target of cyclophilin-cyclosporin A and FKBP-FK506 complexes. Cell 66: $807-815$.

Malleret, G., Haditsch, U., Genoux, D., Jones, M.W., Bliss, T.V., Vanhoose, A.M., Weitlauf, C., Kandel, E.R., Winder, D.G., and Mansuy, I.M. 2001. Inducible and reversible enhancement of learning, memory, and long-term potentiation by genetic inhibition of calcineurin. Cell 104: 675-686.

Margrie, T.W., Rostas, J.A., and Sah, P. 1998. Presynaptic long-term depression at a central glutamatergic synapse: a role for CaMKII. Nat. Neurosci. 1: 378-383.

Mayford, M., Wang, J., Kandel, E.R., and O'Dell, T.J. 1995. CaMKII regulates the frequency-response function of hippocampal synapses for the production of both LTD and LTP. Cell 81: 891-904.

Meyer, T., Hanson, P.I., Stryer, L., and Schulman, H. 1992. Calmodulin trapping by calcium-calmodulin-dependent protein kinase. Science 256: 1199-1202.

Miyoshi, E., Wietzikoski, S., Camplessei, M., Silveira, R., Takahashi, R.N., and Da Cunha, C. 2002. Impaired learning in a spatial working memory version and in a cued version of the water maze in rats with MPTP-induced mesencephalic dopaminergic lesions. Brain Res. Bull. 58: 41-47.

Moore, A.N., Waxham, M.N., and Dash, P.K. 1996. Neuronal activity increases the phosphorylation of the transcription factor cAMP response element-binding protein (CREB) in rat hippocampus and cortex. J. Biol. Chem. 271: 14214-14220.

Mukherji, S., Brickey, D.A., and Soderling, T.R. 1994. Mutational analysis of secondary structure in the autoinhibitory and autophosphorylation domains of calmodulin kinase II. J. Biol. Chem. 269: 20733-20738.

Mulkey, R.M., Endo, S., Shenolikar, S., and Malenka, R.C. 1994 Involvement of a calcineurin/inhibitor-1 phosphatase cascade in hippocampal long-term depression. Nature 369: 486-488.

Robbins, T.W., Mehta, M.A., and Sahakian, B.J. 2000. Neuroscience: Boosting working memory. Science 290: 2275-2276.

Roeper, J., Lorra, C., and Pongs, O. 1997. Frequency-dependent inactivation of mammalian A-type $\mathrm{K}+$ channel KV1.4 regulated by $\mathrm{Ca}^{2+} /$ calmodulin-dependent protein kinase. J. Neurosci. 17: 3379-3391.

Runyan, J.D. and Dash, P.K. 2004. Intra-medial prefrontal administration of SCH-23390 attenuates Erk phosphorylation and long-term memory for trace fear conditioning in rats. Neurobiol. Learn. Mem. 82: 65-70.

Runyan, J.D., Moore, A.N., and Dash, P.K. 2004. A role for prefrontal cortex in memory storage for trace fear conditioning. J. Neurosci. 24: $1288-1295$.

Sawaguchi, T. 2001. The effects of dopamine and its antagonists on directional delay-period activity of prefrontal neurons in monkeys during an oculomotor delayed-response task. Neurosci. Res. 41: $115-128$.

Sawaguchi, T. and Goldman-Rakic, P.S. 1991. D1 dopamine receptors in prefrontal cortex: Involvement in working memory. Science 251: 947-950.

Seamans, J.K., Floresco, S.B., and Phillips, A.G. 1998. D1 receptor modulation of hippocampal-prefrontal cortical circuits integrating spatial memory with executive functions in the rat. J. Neurosci. 18: $1613-1621$.

Sibley, D.R., Leff, S.E., and Creese, I. 1982. Interactions of novel dopaminergic ligands with D-1 and D-2 dopamine receptors. Life Sci. 31: 637-645.

Silva, A.J., Paylor, R., Wehner, J.M., and Tonegawa, S. 1992. Impaired spatial learning in $\alpha$-calcium-calmodulin kinase II mutant mice. Science 257: 206-211.

Smrcka, A.V., Hepler, J.R., Brown, K.O., and Sternweis, P.C. 1991. Regulation of polyphosphoinositide-specific phospholipase C activity by purified Gq. Science 251: 804-807.

Steele, R.J. and Morris, R.G. 1999. Delay-dependent impairment of a matching-to-place task with chronic and intrahippocampal infusion of the NMDA-antagonist D-AP5. Hippocampus 9: 118-136.

Sumi, M., Kiuchi, K., Ishikawa, T., Ishii, A., Hagiwara, M., Nagatsu, T., and Hidaka, H. 1991. The newly synthesized selective 
Runyan et al.

$\mathrm{Ca}^{2+} /$ calmodulin dependent protein kinase II inhibitor KN-93 reduces dopamine contents in PC12h cells. Biochem. Biophys. Res. Comm. 181: 968-975.

Taylor, C.W. 2002. Controlling calcium entry. Cell 111: 767-769.

Taylor, J.R., Birnbaum, S., Ubriani, R., and Arnsten, A.F. 1999. Activation of cAMP-dependent protein kinase A in prefrontal cortex impairs working memory performance. J. Neurosci. 19: RC23.

Toullec, D., Pianetti, P., Coste, H., Bellevergue, P., Grand-Perret, T., Ajakane, M., Baudet, V., Boissin, P., Boursier, E., and Loriolle, F. 1991. The bisindolylmaleimide GF $109203 \mathrm{X}$ is a potent and selective inhibitor of protein kinase C. J. Biol. Chem. 266: 15771-15781.

Ungerleider, L.G., Courtney, S.M., and Haxby, J.V. 1998. A neural system for human visual working memory. Proc. Natl. Acad. Sci. 95: $883-890$.

Uylings, H.B. and van Eden, C.G. 1990. Qualitative and quantitative comparison of the prefrontal cortex in rat and in primates, including humans. Prog. Brain Res. 85: 31-62.
Waters, N.S., Sherman, G.F., Galaburda, A.M., and Denenberg, V.H. 1997. Effects of cortical ectopias on spatial delayed-matching-to-sample performance in BXSB mice. Behav. Brain Res. 84: 23-29.

Young, C.E. and Yang, C.R. 2004. Dopamine D1/D5 receptor modulates state-dependent switching of soma-dendritic $\mathrm{Ca}^{2+}$ potentials via differential protein kinase $\mathrm{A}$ and $\mathrm{C}$ activation in rat prefrontal cortical neurons. J. Neurosci. 24: 8-23.

Yule, D.I. and Williams, J.A. 1992. U73122 inhibits $\mathrm{Ca}^{2+}$ oscillations in response to cholecystokinin and carbachol but not to JMV-180 in rat pancreatic acinar cells. J. Biol. Chem. 267: 13830-13835.

Zahrt, J., Taylor, J.R., Mathew, R.G., and Arnsten, A.F. 1997. Supranormal stimulation of D1 dopamine receptors in the rodent prefrontal cortex impairs spatial working memory performance. J. Neurosci. 17: 8528-8535.

Received November 18, 2004; accepted in revised form February 8, 2005.

\section{Learning \& Memory}




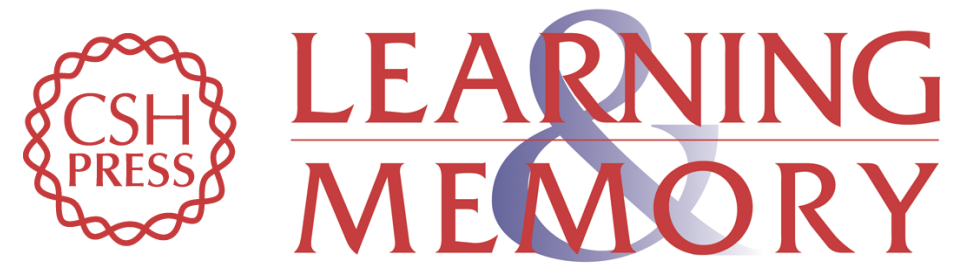

\section{A role for prefrontal calcium-sensitive protein phosphatase and kinase activities in working memory}

Jason D. Runyan, Anthony N. Moore and Pramod K. Dash

Learn. Mem. 2005, 12:

Access the most recent version at doi:10.1101/lm.89405

References This article cites 53 articles, 24 of which can be accessed free at:

http://learnmem.cshlp.org/content/12/2/103.full.html\#ref-list-1

License

Email Alerting Receive free email alerts when new articles cite this article - sign up in the box at the Service top right corner of the article or click here. 